\title{
FINANCIAL MARKETS, DEFAULT, AND BANKRUPTCY: THE ROLE OF THE STATE*†
}

\author{
WiLLIAM H. MeCKLING**
}

\section{INTRODUCTION}

If economists learn anything from the debate which has accompanied recent efforts to rewrite our bankruptcy law, it should be a sense of modesty about our bankruptcy system. As the product of hundreds of years of legal and political history, that system is a very sophisticated and complex institution. Much of the controversy over revising it has revolved about the judicial procedures and administration of the bankruptcy system. These are not subjects on which economists have a comparative advantage, and I shall for the most part behave accordingly.

What economics can contribute to the study of bankruptcy is an analytical framework within which to clarify issues, identify more precisely the role which bankruptcy plays, and assess the social consequences of alternative legal structures.

It is useful at the outset to divide the discussion into two major sub-areas: corporate bankruptcies and all others. The claims on corporations (stocks, bonds, etc.) and the markets in which those claims are traded are sufficiently different from the claims on individuals and noncorporate businesses and the credit markets which they employ to warrant separate attention. In general, claims on corporations do not extend to either the personal assets or wage and salary income of any of the participants. The rights of bondholders, stockholders, creditors, etc., are limited to the assets owned by the corporation. Personal or noncorporate-business borrowing similarly generates claims on the assets owned by the individuals or firms involved; but in addition, such borrowing leads to claims on flows generated by human capital-claims on the wages and salary of the borrower. This fact creates special problems.

The market for human capital is distinctly different from markets for other kinds of capital. Very sophisticated markets have developed in which

\footnotetext{
* This paper was originally presented, in a slightly different form, at the Liberty Fund, Inc., Seminar on the Economics of Bankruptcy at the Law and Economics Center of the University of Miami School of Law (March 31-April 2, 1977). - Ed.

$\dagger$ I am deeply indebted to my colleagues Michael C. Jensen, Clifford W. Smith, and Jerold Warner for helpful comments and for discussions I had with them in the course of preparing this paper.

** Dean, Graduate School of Management, University of Rochester.
} 
claims on future flows from corporate assets are translated into present values and traded regularly; but while individuals can write contracts to provide a flow of labor services, they cannot write contracts selling their labor services for the present value of potential future flows. Thus, there is no market for human capital. Moreover, the courts generally will not enforce specific performance of labor contracts; that is, they will not physically coerce the individual to fulfill such contracts, though they may make him liable for damages.

The division I employ between corporate and noncorporate bankruptcy is a departure from the customary treatment which classifies bankruptcy as either business or personal. I treat individual proprietorship and partnership bankruptcies as part of the noncorporate category because they have more in common with personal bankruptcy than with corporate bankruptcy: both the personal assets and salary or wage income of owners are subject to claims by creditors.

\section{I \\ NONCORPORATE BANKRUPTCY ${ }^{1}$}

A. The Nature of Lending

Bankruptcy grows out of lending. If we want to say anything about what bankruptcy law ought to be, we must understand two things: first, what lending is all about and, second, how credit markets operate. Economists have developed a simple model of lending which has proved to be surprisingly useful both as an analytical and as an expository framework. It is called the two-period consumption loan model.

Suppose two individuals, $\mathrm{L}$ and $\mathrm{B}$, each anticipate receiving income (say, from employment) at the beginning of each of two successive time periods. B's consumption in period 1 will be limited to his income in period 1 unless he can find some other source of funds. Suppose that he would be willing to pay something to increase his consumption in period 1 at the expense of reducing it in period 2. If $\mathrm{L}$ is willing to forego consumption in period 1 in exchange for increased consumption in period 2 (at a price $\mathbf{B}$ is willing to pay), the two can arrive at an agreement which will make them both better off. $L$ and $B$ enter in to a contract: L turns over some of the income he gets at the beginning of period 1 in exchange for a claim on B's income in period 2.

This simple model captures the essence of lending, or credit. The lender gives up a sum of money (or something else of value) now in exchange for a promise from the borrower that he will pay some amount (or amounts) in the future. Using the word "promise" focuses on a problem central to all lending,

1. Section I (A) of this article contains a positive analysis of the operation of financial markets and the effects of noncorporate bankruptcy. Section $I(B)$ is devoted to normative issues which arise out of the analysis of section I (A). Section II is devoted to corporate bankruptcy issues. 
namely, how to give credibility to the borrower's word. The potential borrower wants to persuade the potential lender that he will repay: the more confident the lender is that the borrower intends to repay, the more willing he will be to make the loan.

The desire on the part of borrowers to gain credence with lenders is one of the reasons for granting police powers to the state and having a court system. One way the borrower can help to assure the lender that he will keep his promise is to write into the contract a provision that an outside agency which has the right to exercise physical force may be used to enforce compliance. If government didn't exist to play this role, prospective borrowers would no doubt find a replacement. Once the state's police powers become part of the credit contracting system, the demand for something like courts cannot be far behind. To prevent abuse of the state's powers, an independent judge will be solicited to decide when default has occurred, i.e., when action by the state is justified.

None of the above necessitates the development of an institution such as bankruptcy. With a slight modification of our consumption loan model, however, it is easy to show how a demand for bankruptcy will arise. In our discussion of the two-period consumption loan model we ignored an important issue, namely, uncertainty. Realistically, when B is considering a lending contract at the beginning of period 1 , he (as well as $\mathrm{L}$ ) will be uncertain what B's income will be in period 2. Circumstances over which $\mathrm{B}$ has little or no control could adversely affect his income: sickness, an accident, a recession, etc. If as a result of such an event B finds his income so small in period 2 that he cannot repay the full amount of the claim, he will be insolvent. What happens then? The answer which will immediately occur to most of us is to provide an arrangement under which $B$ will pay what he can and the balance of the debt will be forgiven, i.e., to let B go into bankruptcy.

Bankruptcy can thus be viewed as an institution developed to solve the problem of insolvency. But bankruptcy brings with it problems of its own. If insolvency is to be a prerequisite of bankruptcy, we have the nontrivial task of determining when the individual is insolvent: When is it literally true that someone cannot ever repay his debts? How much do we allow him for his physical sustenance? How do we know what his future earning capacity will be? The latter, it is important to note, is not just a question of our inability to foresee the future. The real problem is that once the debtor and creditor share the debtor's earnings, the debtor will strike a different balance between work and leisure-"leisure" here meaning something much broader than rest and recreation, or even reduced effort on the job. The debtor will have an incentive to seek out income in forms that are exempt from repayment-for example, in employment at which his income is difficult to ascertain or in tasks at home for which no earnings are recorded.

The problem of contractually specifying the correct incentives for the 
leisure-work tradeoff in case of insolvency is only a special example of a more general problem inherent in lending. Debtors, like everyone else, prefer more wealth to less. They will repay only if default is on balance less attractive than repayment. Therefore, the more costly default is to them, the lower is the probability that they will default. Both lenders and borrowers are aware of this fact. The borrower knows that the more confident the lender is that he will be repaid, the more willing he will be to extend a loan, and the lower the interest rate will be. The lender realizes that he must offer competitive terms if he expects to place a loan. Both parties, therefore, have an interest in arriving at a contract which (for a given size of loan) solves the problem of default at the lowest cost. ${ }^{2}$

Contract provisions will increase the probability of repayment if they will impose costs on the borrower if he defaults. Since the borrower knows this, and knows that the lender will grant a lower interest rate in return for a higher probability of repayment, he will himself want to offer a contract under which he will bear costs if he defaults. If restrictions are placed on the extent to which he can agree to impose costs on himself in case of default, the borrower-not the lender ${ }^{2}$ - will be forced to bear higher loan costs. This is because the lender will not agree to make a loan with a higher probability of default unless he is paid a higher interest rate. The lender knows more than the borrower about how alternative contracts affect his operating costs and will of course want to suggest to the borrower provisions which economize on those costs. In the end, however, whatever costs cannot be eliminated will be imposed on the borrower in the form of higher interest.

B. Bankruptcy and the Operation of Financial Markets:

A Positive Analysis

\section{The Economics of Bankruptcy Reform}

\section{a. Financial Markets}

Lending actually takes place under much more complex circumstances than are suggested by our simple model. What has developed (in the Western World, at any rate) is a highly organized market for lending with a large variety of financial institutions acting as intermediaries between lenders and borrowers. If every loan had to be negotiated personally by the individual lender and borrower, borrowing would be a very costly affair. Each party would have the problem of finding someone who was interested in borrowing (or lending) in the right amount and on the right terms. Having found each

2. This is another case of the agency problem. For a more complete discussion of the agency costs involved in contracting, see Jensen \& Meckling, Theory of the Firm: Managerial Behavior, Agency Costs and Ownership Strucutre, 3 J. Financial Econ. 305 (1976). 
other, the parties would then have to negotiate a loan agreement, a process in which neither could be expected to have any expertise. Finally, during the life of the loan the lender would want to monitor the behavior of the borrower and would have to administer the loan. In a purely personal lending system it would be very costly to accomplish all of these tasks, and this explains why financial intermediaries-banks and other lending institutions-come into being.

One way financial intermediaries reduce lending costs is by establishing known central places of business, thereby eliminating the necessity for lenders and borrowers to seek out their counterparts. Another way financial intermediaries reduce lending costs is by introducing standard contracts with lenders and borrowers. Deposit accounts are an example of a standard contract with lenders; consumer loans and mortgages are examples of standard contracts with borrowers. ${ }^{3}$ Financial intermediaries also reduce lending costs by standardizing collection of information about prospective borrowers and by invoking standard rules for evaluating and classifying borrowers as to loan eligibility.

\section{b. The Implications of Financial Markets For Bankruptcy Reform}

One specific contribution which economics can make to the examination of alternative bankruptcy proposals is an understanding of how these financial markets operate. Bankruptcy is, after all, only one feature of a larger system, the financial system. One of the themes that will emerge from the discussion of bankruptcy as a subsystem is that "there's many a slip twixt the cup and the lip"-that consequences which are intended or which seem to follow from some provision in the law are often revealed to be frustrated when we look at bankruptcy not in isolation but as part of a larger system.

The congressional hearings on H.R. 31 and H.R. $32^{4}$ and the report of the Commission on Bankruptcy ${ }^{5}$ make it clear that the urge to revamp the bankruptcy system stems from concern over noncorporate bankruptcy rather than corporate bankruptcy. In part this is simply because noncorporate bankruptcy predominates in number of cases, i.e., in workload and in costs, at least as reflected in the data published by the Administrative Offices of the United States Courts. ${ }^{6}$ But numbers do not provide the major impetus. The record

3. Similarly, charge accounts are standard contracts offered by retailers who to that extent are engaged in offering a financial service.

4. Bankruptcy Act Revision: Hearings on H.R. 31 and H.R. 32 Before the Subcomm. on Cizil and Constitutional Rights of the House Comm. on the Judiciary, 94th Cong., 1st \& 2d Sess., Parts 1, 2, and 3 and Appendix (Comm. Print 1975-1976) [hereinafter cited as House Hearings].

5. Report of the Commission on the Bankruptcy laws of the United States, H. R. Doc. 137, 93d Cong., 1st Sess., pts. 1, 2, and 3 (1973).

6. Annual Report of the Director of the Administrative Office of the United States Courts: Reports of the Proceedings of the Judicial Conference of the United States (1975) [hereinafter cited as AnNual RePORT]. 
clearly indicates that a strong sympathy for the plight of debtors lies behind much of the pressure for revision. Many believe, for example, that under existing law creditors harass and take undue advantage of debtors both before and after bankruptcy has been effected. The proposed legislation that would eliminate misrepresentation ${ }^{7}$ as a bar to discharge in bankruptcy reflects this view, as do efforts to eliminate or strictly control the practice of reaffirmation. ${ }^{8}$

Economic analysis of how credit markets operate, however, reveals that these intentions are doomed to frustration.

\section{c. Short Run Effects-An Aside}

In the short run the potential for benefiting debtors at the expense of creditors is far greater than it is in the long run. At any time there are loan contracts extant. If they have been written with one body of bankruptcy law in mind and the law is then made more lenient, the revision can confer benefits on debtors at the expense of creditors. But subsequent contracts will be written with the new law in mind, and this will mean that transfers from debtors to creditors will not be effected in those contracts.

The history of bankruptcy in the United States casts some interesting light on the nature of short-run effects. ${ }^{9}$ Though the Constitution explicitly granted the federal government the power to enact "uniform Laws on the subject of Bankruptcies," 10 this was left to the states for the first one hundred years of our history, except for three occasions: 1800, 1841, and 1867. The legislation in the first two cases followed financial and economic crises which left large numbers of debtors either unable or unwilling to pay their debts. For example, the 1867 Act reflects the impact of a civil war in which parties to debt contracts were often on opposite sides and loss of life and destruction of real capital had led to insolvency and default on a large scale. Enactment of each of the three laws listed above was followed by a spurt of bankruptcies, after which the law was repealed: the 1800 Act was repealed in 1803, the 1841 enactment (which took effect in 1842) was repealed in 1843 , and the 1867 Act was repealed in 1878. About the 1841 Act, Warren states: ${ }^{11}$

At all events, 33,739 persons took advantage of its benefits, of whom only 765 were refused discharge (with 1,468 still pending in 1862). The amount of debt involved was $\$ 440,934,000$, and the amount of property surrendered by the debtor $\$ 43,697,357$. Owing to expenses of administration, and also owing to the fact that large numbers of the debtors had already been through the State Insolvency Courts, very small dividends were paid to the creditors.

7. A material misstatement of fact in applying for a loan.

8. Reaffirmation occurs when lenders agree to repay all or part of a loan which has been discharged through bankruptcy.

9. See generally C. Warren, Bankruptcy in United States History (1935).

10. U.S. Const. art. $1, \S 8, \mathrm{cl} .4$.

11. C. WARREN, supra note 9 , at 81 . 
About the 1867 Act he says: ${ }^{12}$

In spite of these amendments, the Act of 1867 almost from the outset proved a failure and unpopular everywhere. As time went on, its defects became increasingly evident; and the Supreme Court had occasion to construe it in about 35 cases. Its administration became more and more wasteful. While the number of bankruptcies was not as great as expected, the ratio of voluntary to involuntary was greater (in five years, about 53,000 to 3,300). As reported by the American Law Review, from June 1, 1867, to August 31, 1871, the total number of bankruptcies was 103,005, of which 15,151 were in the Eastern States; 24,534 in the Middle States; 22,780 in the Southern States; 40,097 in the Western States; and 433 in the District of Columbia. The fees to the registers and assignees as officers of the Court more and more absorbed the assets; and the average dividends paid to creditors did not exceed ten per cent.

The 1898 Bankruptcy Act has never been repealed, though it was revised extensively in $1938 .{ }^{13}$ What is currently being discussed, of course, is meant to be a long-run modification of our bankruptcy law; so our primary concern must be with long-run effects.

\section{The Incidence of Bankruptcy Costs}

\section{a. The Elasticity of Consumer Credit Supply}

There are two major sources of credit available to noncorporate borrowers. ${ }^{14}$ These are financial institutions (commercial banks, savings banks, credit unions, consumer finance agencies, etc.) and sellers of goods and services (automobile dealers, retailers, doctors, lawyers, etc.). These sources, however, are often only immediate, not ultimate, sources. If we ask where the bank gets the money it lends or how the department store finances credit, we are thrown into a jungle of complex financial relationships. The department store owes the banks; it owes suppliers; it may have bonds outstanding; if it is a corporation, it will have stockholders who have supplied capital; and so forth. Meanwhile, the bank owes other banks; it owes its depositors; it may itself have loans outstanding to consumer finance companies; and on and on. The fact is that our financial system is a huge network with thousands, indeed millions, of nodes through which funds flow from lenders to borrowers.

There are two points about this system that are important in an analysis of bankruptcy. First, all of the funds that are borrowed must in the end come from individuals; that is, individuals or institutions acting as agents for individuals must be induced to hold voluntarily the claims which debtors offer in exchange for funds. The inducement, of course, is that they earn money for holding the claims.

12. Id. at $112-13$.

13. See 11 U.S.C. $\$ \S 1-1255$ (1970).

14. There are also some minor sources, such as relatives and personal friends. Moreover, some obligations which are considerations in bankruptcy are not the product of borrowing per se; for example, taxes, fines, or a judgment which is levied as a result of an accident. 
Second, these individual potential claimholders have an enormous array of alternative opportunities to extend credit. It is true, of course, that there are a variety of legal constraints imposed on financial institutions-the interest rates they can pay or charge, the kinds of loans or investments they can make, the kinds of deposit service they can offer, etc. But these restrictions do not seriously constrain lending opportunities for the individual. This is not to say that the restrictions have no effect. They do have important effects: they affect the kinds of assets and liabilities that particular types of financial institutions have; they affect the kinds of financial institutions that exist and the numbers of institutions of various kinds; they affect the costs and availability of various types of loans to borrowers. But even with these constraints, the diversity of the investment opportunities available to potential lenders is practically unlimited. As a result, lenders can and do readily adjust to changes in earnings on a particular type of loan. If the cost of lending to a particular class of borrowers rises, lenders shift their assets away from loans to that class of borrowers or charge higher interest rates_or a combination of the two.

Mr. Philip Shuchman, Deputy Director of the Commission on Bankruptcy, expresses an entirely different view of the operation of financial markets. ${ }^{15}$ He advances what he calls the only-game-in-town theory of lender behavior: "For many lenders, therefore, I contend that lending is the only game in town. And if it is not the best game, it is the only one they know." ${ }^{16} \mathrm{Mr}$. Shuchman is saying that in the market where potential bankrupts borrow, the quantity of funds supplied does not depend on the earnings that lenders realize.

Both economic theory and the evidence available are overwhelmingly at odds with that statement. We know that financial institutions have diverse portfolios and that their behavior is very sensitive to changes in potential earnings. Disintermediation is a good example of this sensitivity: when the anticipation of inflation causes an increase in nominal interest rates, we observe financial institutions shifting from kinds of loans on which there are effective interest ceilings (e.g., housing) to kinds of loans on which there are no effective interest ceilings (e.g., business); we see depositors shifting from deposit forms which have ceilings on interest rates (e.g., savings and checking accounts) to forms which do not (e.g., commercial paper, Treasury bills, certificates of deposit); because the discount rate for early payment in most sales agreements is fixed, we see business firms lengthening the time they wait to pay their bills. In one case the combination of inflation and constraints on existing lending opportunities created a new industry: the money market mutual fund industry.

15. Shuchman, An Attempt at a "Philosophy of Bankruptcy", 21 U.C.L.A. L. Rev. 403, 425-28 (1973).

16. Id. at 426 . 
Contrary to Mr. Shuchman's assertion, the evidence indicates that financial markets are very sensitive to earnings potential. Thus, the evidence and economic theory strongly support the proposition that any increase (or decrease) in lending costs brought about by changes in the bankruptcy law will in the long run be passed along to borrowers or potential borrowers as lenders make their adjustment. That is, in economic terms, the supply of funds available for any class of credit $^{17}$ is virtually perfectly elastic at an interest rate determined by the costs of lending in that market-costs defined to include alternative lending opportunities. ${ }^{18}$

\section{b. The Costs of Lending}

We argued above that in a competitive lending market interest rates and loan terms will be set to cover all the costs incurred by lenders. This raises the question what the costs of lending are in markets where potential bankrupts borrow and how those costs are determined. We have already alluded to one of the costs: the costs of foregone lending opportunities. Modern finance theory has introduced the term "riskless rate of return" for a basic alternative opportunity for lenders. For our purposes we can assume that short-term Treasury bills fill this role-that the opportunity to hold such bills offers lenders a virtually certain reward. Before a lender will be willing to extend a consumer loan, he must be offered this riskless rate of return; but in addition, he must be compensated for the risk $^{19}$ he incurs in such loans ${ }^{20}$, plus the

17. In subsequent examples I shall use the term "consumer credit" to cover all the usual forms of credit extended to individuals, individual proprietors, and partners, whether secured or unsecured. While this is somewhat misleading, I believe it does not do serious damage to the analysis, and it avoids the awkwardness of having to specifically consider each type of credit for each subtopic.

18. The question of elasticity is, of course, an empirical one on which it would be desirable to have more direct evidence; but given the evidence we have, this seems the place to start.

19. It is worthwhile at this point to distinguish the use of the word "risk" to mean probability of default on a loan contract from "risk" as it is used in modern finance and portfolio theory, i.e., the covariance of the asset returns with the returns on the investor's entire portfolio of assets. Although it is common to find the term used in the first sense, in fact the default phenomenon is more accurately thought of as a reduction in the mean or expected value of the payoff. Modern portfolio theory emphasizes the notion that the relevant measure of the risk of an individual asset is the amount by which an additional unit of that asset increases the variance of the outcomes of the investor's entire portfolio, and the quantity is proportional to the covariance mentioned above. ( $C f$. Jensen, Capital Markets: Theory and Evidence, 3 Bell J. Econ. \& Manacement SCI. 357 (1972); E. Fama \& M. Miller, The Theory of Finance 276-319 (1972).) I use the term "risk" in this latter sense.

20. Mr. Shuchman also questions whether lenders must be reimbursed for risk: "I would also posit that lenders' behavior does not follow the path of an indifference curve; that the loan which will not be made because too risky at $20 \%$ will not be made even at $30 \%$ (although I assume-but more as a null hypothesis than a likely reality-that at some hypothetical but much higher interest rate the loan may be made.)" Shuchman, supra note 15 , at 427 . Here again the evidence against Mr. Shuchman is overwhelming. Returns on financial claims are positively related to risk. So far as I am aware, economists have never found a single exception of any consequence to that proposition. 
operating costs incurred in engaging in the consumer-loan business. ${ }^{21}$ The latter include the costs of marketing, screening, negotiating, administrating, collecting, monitoring, and counselling as well as losses due to default-including bankruptcy. the higher these costs, the more it will cost individuals to borrow. ${ }^{22}$

Any financial institution that operates in consumer loan markets will have an incentive to minimize the cost of whatever bundle of loans it decides to extend. Many of the activities that generate the various operating costs achieve the same ends in the production of lending services; for example, screening will reduce defaults, but so will monitoring. Thus the extent to which either one is pursued will depend on their relative costs.

For an individual lending institution to minimize the cost of a given bundle of services, it must choose the level of expenditure for each activity in the production of loans so that it will not be able to increase the total service rendered or decrease costs by transferring a dollar of expenditure from one activity to another. For example, to minimize costs it must set the level of expenditure on screening so that another dollar spent on screening would not reduce default losses by more than one dollar.

\section{c. Bankruptcy and the Cost of Borrowing}

An understanding of the principles of cost minimization is helpful when we analyze the impact of revisions to our bankruptcy law. One proposed revision is the elimination of the so-called fraud exception, which prevents debtors from being excused in bankruptcy from repaying loans they obtained by means of misrepresentation in financial statements to lenders. Suppose for the moment that eliminating this defense for creditors will increase the bad-debt losses sustained by lenders, either because nonrepayment is more

21. I owe this tripartite formulation to Clifford Smith. See C. Smith, On the Theory of Lending (July 1976) (Graduate School of Management Working Paper Series No. 7635, University of Rochester).

22. The discussion of credit-system costs is complicated by the difference between costs as perceived by individuals or firms and costs from the viewpoint of society as a whole. When a debtor defaults he imposes a cost on his creditor, but from society's standpoint what the creditor loses the debtor gains. A wealth transfer has taken place, but there is no social cost. Similarly, when an asset is recovered from a debtor and either liquidated or given to a creditor, although the debtor suffers a loss, it is offset in the system as a whole by the gain to a creditor or creditors. The physical asset does not disappear: it is still available to render service or yield an income flow. Again, there has been a wealth transfer but no social cost.

However, when a firm uses resources to conduct credit checks, to monitor loans, and so forth, it is using resources which could be used to produce other output. The same is true of the services of attorneys, judges, buildings, etc., which are consumed in the operation of the bankruptcy system. Payment for these services is not a wealth transfer but a social cost.

In analyzing the behavior of individuals or firms we must view the costs as they perceive them. They will react to a wealth transfer just as they would to a social cost. When evaluating the social consequences of alternative financial systems (including bankruptcy), however, we must separate the social costs from the wealth transfers. 
frequent or because the average amount recovered in case of nonrepayment declines, or both. How will financial institutions react? They will increase expenditures on those activities which reduce bad-debt losses. They will establish stricter standards for loan recipients, rejecting some applications they would otherwise have taken. They will spend more resources collecting information about applicants. They will monitor loans more carefully, notifying debtors more promptly when their payments become overdue, or perhaps imposing higher penalties for late payments. They will insist more on pledges of specific collateral. In brief, they will reequate the marginal value of a dollar's worth of expenditure on each activity which goes into making these kinds of loans. Despite these actions, the firms will ultimately incur larger losses from bad debts. In general, it will not pay them to reduce those losses to the level that prevailed prior to the change in the law; for if it did, this would imply that they had not been optimizing before the law changed. Unless the elimination of the fraud exception somehow reduces costs elsewhere in the lending system, the net effect will be an increase in lending costs as seen by the firms.

\section{d. Who Bears the Increases in Lending Costs?}

For the reasons discussed above, all increases in lending costs as perceived by lenders will in the long run be borne by potential borrowers. No doubt much of the market adjustment will take the direct form of higher interest rates: those who are still able to borrow will find that they must pay more to the lender for the privilege. Borrowers will also find that the total amount of credit available to them as individuals is reduced. ${ }^{23}$ Finally, some potential borrowers will be forced out of the market entirely by higher interest or more stringent screening. To the prospective borrower who is denied a loan the inability to obtain credit is of course a cost, though it takes a different form from the costs imposed on those who are still able to borrow. In other words, if efforts to afford relief to debtors increase lending costs as perceived by lenders, those additional costs will be borne by borrowers as a group. It is not possible to impose those costs on lenders in the long run.

The extent to which specific borrowers or a specific group of borrowers in the consumer loan market bear the increased costs of reducing bad-debt losses depends on the costs to financial institutions of sorting potential borrowers on the basis of the bad-debt losses they are likely to cause. Lenders who find low-cost ways of distinguishing low-default-probability borrowers from highdefault-probability borrowers will be able to attract the former away from competitors by offering loans to them on better terms. If it is very inexpensive to classify potential borrowers by their probability of default, there will be

23. Since a borrower who has given assets (including human capital) is not the same borrower when his debts are $\mathrm{D}$ as when they are $\mathrm{D} \Delta \mathrm{D}$, restrictions on the total credit extended at a given interest rate are really equivalent to an increase in the interest rate 
many different subgroups borrowing on different terms. The cheaper it is to identify potential bankrupts, the narrower the base will be on which the increased costs of bankruptcy are imposed. If it is costless to predict perfectly which borrowers will go into bankruptcy, no bankruptcy costs will be imposed on borrowers who will repay their loans. Borrowers who would certainly go bankrupt will bear all the costs: they will simply be unable to obtain loans.

Benston provides an excellent example of how financial markets adapt to cost changes in his study of the impact of the regulation of consumer finance companies in Maine. ${ }^{24}$ In an effort to keep certain debtors from being continually indebted to consumer finance companies, the state of Maine enacted a law which strictly limited renewal and extension of old loans. ${ }^{25}$ Benston found that renewals and extensions were integral and essential aspects of the way consumer finance companies did business under state ceilings on the interest rates they could charge. Initial loans extended by them tended to be small and, considered alone, generated losses for the firms. These loans, however, provided the firms with information about the reliability of the borrower and gave the borrower an opportunity to find out about the treatment afforded by the firm. Thus, these loss-leaders often led to extensions and further advances of funds for those borrowers who paid-in other words, to a long-term relationship which was profitable for the firm.

Benston found that after passage of the law, the number of consumer finance companies operating in the state and the number of offices they operate dwindled and finally disappeared. ${ }^{26}$ As a result, half of the former consumer finance customers interviewed by Benston who wished to borrow further were unable to obtain loans. Forty percent of the half who could obtain loans obtained them from consumer finance companies, which have since disappeared. ${ }^{27}$

\section{The Impact of Legal Reform on Bankruptcy Costs}

Our analysis to this point suggests that if changes in bankruptcy law increase bad-debt losses, additional lending costs will be borne by debtors and potential debtors. We have not addressed the question how legal modifications are likely to affect the probability that individuals will elect nonrepayment, nor have we addressed what effect such modifications are likely to have on the amount that creditors recover.

Bankruptcy proceedings can be initiated either by a debtor or by a cred-

24. See Benston, The Impact of Maturity Regulation on High Interest Rate Lenders and Borrowers, $4 \mathrm{~J}$. Financial Econ. 23 (1977), reprinted in Law \& Contemp. Prob., Autumn 1977, at 180. Of some interest here is the fact that this change in the law was apparently due largely to the efforts of a bankruptcy judge.

25. 1967 Me. Acts. $474, \S 5$ (amending ME. Rev. Stat. tit. 9, $\S 3081$ ).

26. Benston, supra note 24 , at 25 .

27. Id. at 48-49. 
itor. In practice all but a very small fraction of bankruptcies are at the initiative of the debtor. In fiscal 1974, for example, about 188,500 bankruptcies were initiated by debtors and about 1,000 by creditors. $^{28}$

\section{a. The Debtor's Choices}

An individual debtor's decision to resort to bankruptcy is a function of the costs and benefits to him of alternative courses of action. A debtor who is considering bankruptcy, however, is not faced with a simple dichotomous choice between repayment and bankruptcy. In addition to repayment he has three alternatives: straight bankruptcy, rearrangement of payments, or default.

\section{i. Straight Bankruptcy}

In straight bankruptcy a debtor gives up all of his assets (except for some amount, called an exemption) in exchange for a discharge of all his debts. If he elects straight bankruptcy, the bankruptcy court will permit him to retain assets in accord with the exemptions allowed in the state where the bankruptcy occurs. The balance of his assets will either be recovered by creditors who have secured claims or taken by the court and liquidated to repay obligations, including the cost of bankruptcy proceedings. The benefit of straight bankruptcy to the debtor consists of a complete discharge of interest and principle payments on outstanding debt. The costs to the debtor consist of: loss of assets that are recovered by creditors or taken by the courts for liquidation; payment by the debtor for services rendered in the bankruptcy proceedings that are not charged against the proceeds of liquidation (attorneys' fees or filing fees, for example); adverse effects on future borrowing; ${ }^{29}$ and psychological or other costs that the individual might suffer because of his failure to fulfill a contract.

\section{ii. Rearrangement of Payments}

A debtor can elect to bargain with his creditors for extensions, compositions, amalgamations, etc. He can do this on his own or through official channels, either under the Bankruptcy Act or through procedures provided

28. House Hearings, supra note 4 , at 39 .

29. The question of the effect of bankruptcy on future borrowing has led to considerable confusion in the literature, because discharge of debts has two effects which work in opposite directions. The discharge frees the debtor from obligations he otherwise would have to meet out of current cash flows. To that extent, it increases the probability that he will repay any new loan, and therefore makes him a better prospect. But the fact that he has gone bankrupt means that potential lenders will discount the value of his promises to pay, and this will reduce their willingness to lend to him. A correct statement of the effect is that the schedule of rates of interest the borrower will have to pay as a function of the net debt he has outstanding shifts upward. 
in state or common law. If a debtor elects some repayment arrangement, such as chapter XIII of the Federal Bankruptcy Act, ${ }^{30}$ he will benefit from rearranged or increased net cash flows. He will not, however, be discharged from all of his obligations, and he therefore will not have as large an improvement in net cash flow as he would if he elected straight bankruptcy. He can retain some assets that he might have to give up in straight bankruptcy, and he might even retain some secured assets that would be taken if he simply defaulted. He can perhaps realize some benefit from having a single source (i.e., the court) handle his payments. Through this procedure he can limit or eliminate the ability of creditors to impose costs on him in their attempts to collect. Finally, since he is repaying at least some of his obligation, he may feel less guilty than he would in straight bankruptcy or default.

\section{iii. Default}

A debtor can simply elect not to repay a loan or loans; that is, he can default without going into bankruptcy. If he elects to default, he benefits by increasing his cash flow net of payments. If he is able to retain assets whose value exceeds that which he could retain as exemptions under straight bankruptcy, default will to that extent be preferable to straight bankruptcy. However, default opens the way to action by creditors. Creditors can legally impose costs on the debtor in attempts to force repayment or to recover assets, e.g., garnishment of the debtor's wages, telephone calls at 2:00 a.m., or clandestine recovery of his car. If knowledge of the default becomes available to other lenders, default will also impose costs by adversely affecting the debtor's ability to borrow. The debtor may also incur psychological costs from reneging on a contract.

\section{b. The Effects of Legal Reform}

Straight bankruptcy, repayment arrangements, and default are alternatives, but they can also be sequential states. Some level of default of ten precedes bankruptcy, and it is quite common for bankrupts to try a repayment arrangement prior to straight bankruptcy. A debtor who has been discharged in straight bankruptcy, however, cannot use that option again within six years.

Straight bankruptcy is by far the most popular option among bankrupts who use the federal bankruptcy courts. In 1975 there were 254,484 bankruptcy filings in the federal courts. Of these 208,064 were straight bankruptcies and only 41,178 (sixteen percent) were repayment arrangements under chapter XIII. ${ }^{31}$

30. 11 U.S.C. $\S \S 1001-1086$ (1970).

31. AnNual Report, supra note 6 , at 154 . The other $2 \%$ were scattered under other sections of the Act. 
Changes in bankruptcy law which lower the costs or raise the benefits to debtors of one of those three options will without question increase both the number of debtors who elect that option and the total number of debtors who elect one of the three in preference to repayment. After such a change, more debtors will find one of the three more desirable than repayment, while no debtor will find repayment more desirable than before.

How this will affect bad-debt losses, however, is unclear. Suppose, for example, that the costs to debtors of resorting to rearrangements under chapter XIII are reduced. Some debtors who would have (marginally) chosen straight bankruptcy will now choose chapter XIII. If this leads to recovery by creditors of a larger fraction of the amount due, bad-debt losses will to that extent decline. The effect on total bad-debt losses then depends on how that additional recovery compares with the new losses that will be incurred when individuals elect to slip from repayment to nonrepayment.

\section{Bankruptcy and the Financial System: Summary}

Our analysis of bankruptcy and the operation of the financial system leads us to these conclusions:

1. Revisions to the bankruptcy law designed to benefit bankrupts are very likely to increase lending costs as perceived by lenders.

2. Those increased costs will be borne by borrowers or potential borrowers, partly in the form of higher interest rates and partly in the form of denials of loans.

The proposals currently under consideration to eliminate misrepresentation as a bar to discharge or to prevent or control reaffirmation are cases in point. The major effect of those revisions will be to transfer wealth from those who repay loans and those who are denied loans to those who get loans but do not repay. Whether one approves or disapproves of that result is of course a separate question-one which is not totally intractable but in the end depends on one's personal values.

\section{Normative Issues in Noncorporate Bankruptcy}

It is ultimately individuals who borrow and lend, even if they do so through agents. If borrowing and lending is voluntary, we must assume that both of the parties to the transaction believe they will thereby be better off.

The issue in evaluating bankruptcy is whether the law can improve on the results of this voluntary process.

It is important for any discussion of what bankruptcy law ought to be to separate two functions which have to be performed as part of controlling the default problem. One of these is the task of specifying the contract terms which spell out the rights of the parties in case of default. The other is the task of ensuring that those terms are carried out if default occurs. The latter 
function, of course, has been assigned to the courts. Using the police powers of the state, the courts are responsible for ensuring that the consequences of default on a contract accord with the contract's terms. Because that function relies on the use of the state's police powers, and because of the desirability of a state monopoly on police powers, it is difficult to see how any agency other than the courts could effectively play the enforcement role. No doubt the way they carry out this function could be improved, but that is not our primary concern here.

The issue in bankruptcy law lies in its effect upon the former function, contracting, and the freedom of individuals to write whatever loan contracts they choose. If parties were free to write anything they wished into a loan contract, there would be many ways the borrower could agree to impose costs on himself for default. He could agree to suffer physical pain, go to prison, become an indentured servant, forfeit certain assets (i.e., collateral), allow his wages to be garnished, and so on. In fact, in the United States today the borrower is denied legal sanction for many of these alternatives. For example, a borrower who writes a contract which says that he will go to prison if he defaults cannot have the contract enforced in our courts. Yet we know that individuals willingly agree to contracts which have very similar default conditions, even if unwritten. We observe borrowers accepting extralegal contracts that will with high probability lead to bodily injury if they default. Another example is the provision that individuals can voluntarily go into bankruptcy. This provision automatically makes the election of bankruptcy a part of all lending contracts. What that really means is that the courts and the police powers of the state will not be used to enforce a contract in which an individual waives his right to go bankrupt. ${ }^{32}$

As a result, potential debtors cannot enter into enforceable contracts which bind them beyond the limits prescribed in the Bankruptcy Act. The limits take two forms. One is asset exemption. ${ }^{33}$ This feature of the law limits the nonhuman wealth a debtor can pledge as general security for his debts by limiting the assets available in the settlement of creditors' claims. The second form of limitation is on the size of the claim debtors can grant on their human wealth, their wage and salary income. Both lenders and borrowers regularly enter into loan contracts in expectation of repayment out of wage and salary income. Since there are no markets in which individuals can con-

32. It is such contracting limitations combined with maximum interest rates which foster the development of extralegal credit markets. Individuals denied the right to legal credit markets by restrictions on contracting there voluntarily engage in contracts which entail very serious costs for nonrepayment. Since the courts and the police powers of the state cannot be used in such markets to enforce contracts, enforcement is supplied by private agencies, e.g., organized crime.

33. Since the $1889 \mathrm{Act}$ the exemptions have been state determined and have varied from state to state. One of the major thrusts in the proposed revisions is to have the federal government invoke uniform exemptions. It is worth noting that the objective here, equal treatment across the country, is also a very elusive goal. 
tract to sell their future labor services at capitalized values, such loans provide the means for borrowers to adjust their consumption patterns over time. Under our bankruptcy law, however, potential debtors cannot enter into enforceable contracts which provide unconditional claims on wage and salary flows. The courts will not enforce such claims even if the two parties have agreed to them.

It is not too difficult to see why the state has prescribed limits on the individual's rights to contract to be imprisoned or to be beaten if he defaults on loan contracts. ${ }^{34}$ Those kinds of limitations probably raise the cost of lending a little and may force some borrowers into extralegal markets, but the overall effect is probably negligible. It is much less understandable why the state wishes to limit the individual's right to decide what claims he can offer on his labor income. This will significantly increase borrowing costs and will ultimately transfer wealth from borrowers who repay their loans, and from individuals who are denied loans in regular credit markets, to bankrupts. This wealth transfer would hardly get hearty applause from the general public. ${ }^{35}$

Note that defending the right to contract is not the same as advocating draconian punishment for debtors. To suggest that prospective borrowers be allowed the freedom to agree to imprisonment or wage garnishment is not to demand the requirement of those penalties in every contract.

\section{II}

\section{Corporate BankRUPtCy}

\section{A. Introduction}

The corporation is a legal fiction which serves as a nexus for a set of contracts $^{36}$ - contracts with suppliers, labor, customers, creditors, bondholders,

34. In the light of comments by both discussants and participants at the Liberty Fund Seminar, this paragraph cries out for revision. The problem is that $I$ have shifted from a normative to a positive discussion, the latter consisting of statements about why the political system has generated the kind of law it has.

35. A special problem associated with bankruptcy deserves mention. As the probability that a debtor will elect bankruptcy increases, it pays individual creditors qua individuals to use pressure to collect their particular debts. If the debtor has limited ability or willingness to pay his debts, individual creditors have a strong incentive to collect on their claims before the debtor elects bankruptcy proceedings. In deciding whether to put pressure on the debtor, the individual creditor will not take into account the costs he may impose on other creditors, particularly the losses others will incur if the debtor decides to go into bankruptcy. The issue here is whether creditors as a group could develop a repayment plan (which might involve extension or composition, or both) to which the debtor would agree and which would make the creditors as a group better off. Such agreements could reduce the system costs of lending and thereby yield positive social benefits.

36. For a more complete discussion of the corporation, see Jensen \& Meckling, supra note 2. Corporations are often treated as if they were individuals. For some purposes that practice can be a convenient and harmless simplification. For other purposes, however, it is extremely important to understand that the corporation is not in fact a person. For example, it is not possible to 
stockholders, etc. Generally these contracts give individuals claims on the current and future resources of a firm; for example, they will require cash payments to lenders at specified times ${ }^{37}$ Because such contracts look to the future, their fulfillment is uncertain. The parties to the contracts, understanding that they are confronted by uncertainty, will attempt to deal with that problem in their contracts. Thus, a firm will be willing to agree to a variety of constraints on what the managers of the firm may do-limits on dividend payments, limits on new borrowing, minimum ratios of current liabilities to assets, and the like-all designed to reduce the probability that the firm will default on its obligations. The contracts will also provide ways for creditors to monitor the firm's activities. For example, the management will be required to supply creditors with independently audited accounting information. ${ }^{38}$ All of these activities are of course costly, and it will pay creditors and debtors of the corporation to pursue them only so far. In the end there will still be a chance that the corporation will be unable to fulfill all of its outstanding claims. Bankruptcy is a legal institution designed to handle that situation.

It would be convenient for both analysis and policy if bankruptcy could be confined to cases in which the financial difficulties of a firm were the product of events outside the control of the firm. The optimal bankruptcy system would then simply be the one which minimized the cost of settling the affairs of firms encountering bad luck. But bankruptcy cannot be limited to externally caused difficulties, because bankruptcy law affects the behavior of the parties to corporate contracts, especially the behavior of management. Imagine, for example, what would happen if the law were altered to provide that stockholders had first claim on the value of a firm in case of bankruptcy and creditors got the residual. ${ }^{39}$ Stockholders would certainly find bankruptcy more attractive, and managers acting in the stockholders' interest would be much less cautious of actions which increased the probability of bankruptcy; for example, they would be induced to undertake more risky investments. Knowing this, creditors would be reluctant to lend to corporations at former interest rates. In an effort to offset the higher interest rates they would be required to pay, stockholders would offer to impose additional constraints on management, provide more extensive monitoring opportunities, and so forth;

\footnotetext{
impose costs on a corporation, even though we sometimes say such costs are imposed. Costs can only be imposed on individuals.

37. Firms will issue some nonequity claims, that is, some risky debt, because of the costs associated with a $100 \%$ equity capital structure.

38. Watts has discussed numerous examples with a more careful analysis of such monitoring and bonding activities. Watts, Corporate Financial Statements, A Product of the Market and Political Process, 2 Australian J. Management 53 (April 1977).

39. This is not, incidentally, such an unrealistic assumption; indeed, it is not very different from the practice of discharge of individuals in straight bankruptcy. In effect the right of discharge gives the borrower title to the whole flow from his human capital if he elects straight bankruptcy, as well as title to whatever assets are exempted from creditors' claims.
} 
but they would not in general be able to push interest costs down to what they were when creditors were given first claim on a firm's resources in bankruptcy. ${ }^{40}$ Because bankruptcy law affects the decision to resort to bankruptcy, the optimal corporate bankruptcy system must fulfill two requirements: (1) it must generate the optimal number of bankruptcies, and (2) it must do so at minimum cost.

\section{B. Some Facts about Corporate Bankruptcy}

While corporate bankruptcy constitutes only a tiny fraction of the bankruptcy caseload, it represents a much more significant fraction of the total assets or liabilities at issue in bankruptcy. Altman reports the assets of major corporations which entered bankruptcy in 1970 and the first half of $1971 .^{41}$ The corporations which Altman lists as filing for bankruptcy in 1970 (not including the Penn Central) had assets with a total value of $\$ 814$ million. Presumably the claims of creditors exceeded that amount. By comparison, Stanley and Girth report: ${ }^{42}$

No figures have been published since 1964 on the amount of claims allowed in no-asset bankruptcy cases. The claims of creditors in all bankruptcy cases concluded in that year, including Chapter XI and Chapter XIII proceedings, totaled $\$ 1,808$ million, while creditors were paid or promised payment of about $\$ 99$ million . . . . The estimates we prepared suggest that the claims of creditors in cases concluded in 1968 amounted to $\$ 2,168$ million; that the creditors were paid or were promised payment of $\$ 131$ million. . .

The Federal Bankruptcy Act provides two separate frameworks within which corporations may undergo bankruptcy: chapters $\mathrm{X}^{43}$ and XI. ${ }^{44}$ Chapter XI proceedings can be instituted only by a firm itself. A firm can become bankrupt under chapter $\mathrm{X}$ either on its own petition (i.e., voluntarily) or on the petition of three or more creditors with claims totalling $\$ 5,000$ (i.e., involuntarily). According to Altman, "Chapter X proceedings apply, in effect, to all publicly held corporations, except railroads, and to those which have secured creditors." 45 More recently, however, large corporations frequently make use of chapter $\mathrm{XI}:{ }^{46}$

Chapter XI, which was originally designed for small "mom and pop" types of businesses, has been molded and fashioned for use by large publicly-owned

\footnotetext{
40. Here again we must be careful to distinguish social costs from private costs. The social costs consist of the resources used in monitoring and bonding activities, plus any welfare losses which result from constraining managerial behavior. Interest and bad-debt losses are private costs which will affect firm behavior, but they are not social costs.

41. E. Altman, Corporate Bankruptcy in America 17 (1971).

42. D. Stanley, M. Girth, V. Countryman, G. Jantscher, W. Law, V. Rosenblum, \& M. Shimm, Bankruptcy: Problem, Process, Reform 22-23 (1971).

43. 11 U.S.C. $\$ \$ 501-676(1970)$.

44. 11 U.S.C. $\$ \$ 701-799$ (1970).

45. E. Altman, supra note 41 , at 7 .

46. House Hearings, supra note 4 , at 1874 .
} 
and financed business entities whose capital and debt structures have often been complex.

The W.T. Grant bankruptcy was originally filed under chapter XI but was subsequently converted to chapter $\mathrm{X}$, and the firm liquidated. Many bankruptcies under chapter XI are noncorporate business bankruptcies. There were a total of 3,506 filings under chapter XI in $1975,{ }^{47}$ compared with 2,171 in fiscal 1974. ${ }^{48}$ There were 189 filings under chapter $X$ in fiscal 1975; of those 20 were involuntary petitions. ${ }^{49}$ In fiscal 1974 there were 163 filings under chapter X, 11 involuntary. ${ }^{50}$

Bankruptcy proceedings can lead to liquidation (i.e., sale of assets and dissolution of the firm) or reorganization and continued operation in some form. With large firms the objective of the petitioner is almost always reorganization. The decision whether reorganization is to be attempted is the legal responsibility of the referee, or bankruptcy judge. The reorganization plans are prepared by trustees appointed by the judge or by the management, if they remain in control. Reorganization plans must be approved by the court, creditors, and in some cases even stockholders.

\section{Settlement of Claims in Reorganization}

Settlement of claims on bankrupt corporations that are liquidated has apparently worked well enough to preclude controversy. Such is not the case, however, with reorganizations. One of the major concerns of the courts and the Congress has been whether the various parties, particularly the public in publicly held firms, are treated fairly in bankruptcy reorganizations. While "public" here nominally refers to both bond and stock holders, it is really the stockholders who are the prime object of concern.

The courts, the Congress, and the Securities and Exchange Commission refuse to relegate stockholders to the status of purely residual claimants. Altman cites several cases-for example, Muntz $\mathrm{TV}^{51}$ - in which not only were creditors not fully repaid before stockholders got something of value but stockholders actually fared better than unsecured creditors. ${ }^{52}$ In a sample of ninety corporate bankruptcies Altman found forty instances in which stockholders shared in the settlement. ${ }^{53}$ It is difficult to reconcile the proposition that a firm is bankrupt with the proposition that stockholders have some positive equity. The idea that a firm can somehow be solvent in the long run but

47. ANNUAL REPORT, supra note 6 , at 154.

48. House Hearings, supra note 4 , at 39.

49. AnNual RePort, supra note 6, at 154.

50. House Hearings, supra note 4 , at 39.

51. See In re Muntz TV, 229 F.2d 228 (7th Cir. 1956); In re Muntz TV, 225 F.2d 489 (7th Cir. 1955).

52. E. Altman, supra note 41 , at 103 .

53. Id. at 133 . 
temporarily unable to meet its obligations will not withstand careful scrutiny. If the firm has a present value which exceeds the sum of the claims held by creditors, it should always be able to meet its current cash-flow requirements simply by substituting new loans for old. It is true, of course, that firms can be involuntarily thrown into bankruptcy under chapter $X$, but since the number of involuntary bankruptcies is only ten percent of the total, that cannot explain why stockholders frequently get valuable claims in corporate reorganizations.

A parallel between corporate and noncorporate bankruptcy is worth noting. Earlier we argued that the costs of noncorporate bankruptcy will be borne by debtors - that it is not possible to transfer wealth from lenders to borrowers. A similar proposition holds for corporate bankruptcy. The generosity with which the courts and the law treat various groups of creditors in bankruptcy will be taken into account in the prices of their various financial claims. From the standpoint of the shareholder the cost to the corporation of credit in various forms, such as bank notes, accounts payable, etc., will reflect the bankruptcy treatment anticipated for each class of credit. If efforts to treat stockholders more generously in bankruptcy ultimately impose costs on the bankruptcy process, those costs will in the main be borne by shareholders in the form of higher borrowing costs and reduced credit. ${ }^{54}$

While it is important to recognize the sensitivity of financial markets to the costs bankruptcy law can impose on the financial system as a whole, it is easy to exaggerate the impact of bankruptcy law on the treatment of various parties in bankruptcy. Individuals interested in maximizing their own wealth will act to frustrate laws calculated to transfer wealth from them to others. In this context notice that erratic behavior by the courts, behavior which makes it very difficult for participants in the market to predict the outcomes of contracts, is itself a source of costs. There is much to be said for uniformity in application of the law, whatever the law is.

There are three factors which appear to account for the favorable treatment of stockholders in bankruptcy:

\section{The Difference Between Liquidation Value and Going-Concern Value}

One factor which affects the treatment of shareholders in bankruptcy is the power which they and management have under chapter XI proceedings.

In the hearings on the proposed new bankruptcy law the testimony submitted by the National Bankruptcy Conference states the problem as follows: 55

54. The extent to which costs are imposed on lenders depends on the elasticity of supply of credit to corporations. As in the case of consumer lending, however, the abundance of alternatives open to lenders suggests that the relevant elasticity is large, that is, that most of these costs will be borne by stockholders.

55. House Hearings, supra note 4, at 1874-75. 
The history of the development of reorganization techniques and the evolution of bankruptcy legislation represents a balancing of the relative rights of creditors and the debtor as well as the persons who may be indirectly affected by reason of a failure to rehabilitate or reorganize a distressed business. Consistent therewith is the concept that an insolvent corporate debtor in reality holds corporate assets for the benefit of its creditors. A review of the present use of Chapter XI may demonstrate that in theory and practice the creditors whose theoretical assets usually remain subject to the control of the debtor's management, are in a most disadvantageous position. ... In substance, important elements of creditor safeguards are lacking under Chapter XI because (1) there cannot be an involuntary Chapter XI case, and (2) creditors who may be the real parties in interest are precluded from proposing a plan under Chapter XI. ... [U]nder the present Chapter XI the debtor may have unnecessary power to force creditors to yield to the terms of its proposal. Within certain limits, the Chapter XI debtor can effectively dictate the essential ingredients of a Chapter XI plan to its creditors. In many cases, the alternative to creditors may be to accept the proverbial "ten cents on the dollar" offered or be confronted with an adjudication in bankruptcy and the resultant liquidation. The bargaining power of creditors in such circumstances may be severely limited. The substantial loss that may be faced by creditors as a consequence of the forced auction sale of work in process, inventory, machinery and plant may be overwhelming.

In some Chapter XI cases, a settlement proposal is made on condition that a major and controlling stockholder be offered a substantial sum for his interest in the business while the return to creditors is minimal. Indeed, creditors may not be privy to the negotiations of such a stockholder and the arrangements which he may make concerning the financing of a Chapter XI plan and the sale of the principal's interest; a result which could not occur under Chapter $\mathrm{X}$.

Of course, the bargaining position of the debtor under present Chapter XI may be further enhanced by the debtor's control of the business and the fear that a debtor through intermanipulation may destroy or diminish the value of the business if creditors do not acquiesce to the debtor's Chapter XI plan. The take-it-or-leave-it attitude on the part of debtors as permitted by Chapter XI is fraught with potential abuse.

In brief, there can be a positive difference between the going-concern value of a firm and its liquidation value. Given the procedures of chapter XI, owners of the firm are in a position to take all or much of this difference even if creditors are not fully repaid.

Trost states the issue very pointedly in comparing proceedings under chapter XI and chapter $X:^{56}$

Under Chapter XI, any plan which provides creditors with as much or more than they would receive upon liquidation meets the statute's command that the plan must be in the "best interests" of creditors. Thus, shareholders of an insolvent Chapter XI corporation may retain an interest in the reorganized corporation even though creditors are not paid in full. But in Chapter X reorganizations the court applies a quite different rule: Unless the corporation is solvent, shareholders cannot participate in the fruits of the reorganization because of the application of the so-called "absolute priority" doctrine.

56. Trost, Corporate Bankruptcy Reorganizations: For the Benefit of Creditors or Stockholders?, 21 U.C.L.A. L. REv. 540, 540-41 (1973). 
The procedures of chapter XI provide an extreme example of the impact that bankruptcy law can have on the decision to file for bankruptcy. Since stockholders (through management) have the right to petition for bankruptcy, they will do so whenever the present value of the cash flows which their claims would yield if the firm continued in operation falls below the present value of the claims they would receive in a reorganization. If by filing stockholders can capture more of the difference between the liquidation value of the firm and the going-concern value than they would by continuing operation, it will pay them to throw the firm into bankruptcy, even though it is perfectly solvent. It is of course conceivable that it will also be in the interest of creditors to throw the firm into bankruptcy when it is still solvent; for example, if the stockholders would otherwise consume the assets. But on balance it would appear that the burden of proving that the procedural framework invoked in chapter XI is efficient-that is, that it produces the optimum number of bankruptcies at minimum cost-ought to be on those who defend chapter XI procedures.

\section{Overestimating the Value of the Reorganized Firm.}

The second factor which enables shareholders to emerge from bankruptcy with positively valued claims is the procedure under chapter $\mathrm{X}$ for establishing the value of a reorganized firm. De facto that task has largely been turned over to the staff of the Securities and Exchange Commission. Some of the difficulties with the results are discussed by Trost: ${ }^{57}$

Corporations in reorganization are valued as a going concern by capitalizing the prospective earnings of the rehabilitated corporation. Although market values, liquidation values, and past earnings records may be relevant, they are not determinative. . . Some courts and commentators are more candid than others about the difficulties inherent in the valuation problem. . . Particularly troublesome is the choice of the proper capitalization rate. Assuming that future earnings can somehow be forecast, a change in the capitalization rate one-half point up or down can have momentous consequences for junior interests . . . . By a slight change of the capitalization rate, an insolvent company in which shareholders are denied participation becomes a solvent company in which shareholders are entitled to some kind of interest. "[I]t seems not unlikely that implicit in the choice of a rate may be the desire to rationalize a predetermined result, as for instance, the retention of the common stockholders in the enterprise."

Warner also describes the valuation procedure and discusses a hypothetical example designed to illustrate its problems: ${ }^{58}$

The usual procedure for valuing the firm is to capitalize estimated post-tax earnings in perpetuity. Whether or not a particular class of claimholder can

57. Id. at 545-46, quoting Gardner, The SEC and Valuation under Chapter X, 9I U. PA. L. REv. 440, 453 (1943).

58. Warner, Bankruptcy, Absolute Priority, and the Pricing of Risky Debt Claims, 4 J. Financial. ECoN. 239, 244 (1977). 
be included in the settlement then depends upon the estimated value of the firm. A class will be compensated if the estimated value of the firm is greater than the face value of all claims senior to it.

The consequences of the valuation procedure can best be illustrated with a simple example. Suppose that a firm were unable to pay its debt currently due, which consisted of "senior" bonds with face value of $\$ 10$ million, and "junior" bonds with a face value of $\$ 15$ million. Suppose that the firm were to file a bankruptcy petition and the claimholders had decided not to liquidate. The appropriate regulatory agency estimates the value of the firm as a "going concern", based on the firm's hypothesized new capital structure, an estimate of future post-tax earnings, and an assumed capitalization rate.

Suppose the firm were "valued" at $\$ 15$ million. Given the valuation, senior bondholders would be given new claims with face value (and estimated "intrinsic value") of $\$ 10$ million, and junior bondholders would be given claims with a face value (and estimated "intrinsic value") of $\$ 5$ million. Suppose that the actual market value of the firm were $\$ 12$ million, and that the new claims given senior and junior bondholders turned out to have market values of $\$ 8$ million and $\$ 4$ million, respectively. Then the senior bondholders receive $\$ 2$ million less than they would have received had the satisfaction of their priorities been based upon market values, and the junior bondholders receive $\$ 2$ million more than they would have received.

Warner's example shows how overestimates of the total value of a firm subvert the intent of absolute priority. The issue in valuation is not simply error in the estimates but bias - systematically overestimating the value of the reorganized firm in order to give something to junior creditors and stockholders.

\section{Retaining the Management}

The third factor which enables stockholders to share in reorganization settlements is a very different phenomenon. There are apparently occasions on which it pays creditors to concede something to shareholders in order to keep the current management.

Trost argues that absolute priority ought to be abandoned as a criterion in chapter $\mathrm{X}$ cases because it is sometimes inimical to creditor welfare, particularly where creditors have a strong interest in retaining the management. ${ }^{59}$ In his testimony at the hearings on the new bankruptcy legislation, he gave an example: ${ }^{60}$

That case [U.S. Financial] operated in chapter XI for 2 years, even though it was a public company. It was changed over to a chapter $X$ case. It operated in chapter XI with the acquiescence of the Securities and Exchange Commission, with the acquiescence and desire of all the creditors, but for three; and it operated smoothly. And the reason that everybody wanted it in chapter XI was because they did not want to change management.

The management of this company that had been defrauded by people who are now going to jail, had changed prior to filing. The reason the chapter XI was filed was to preserve the existence of the current management.

59. See Trost, supra note $\mathbf{5 6}$, at 552 .

60. House Hearings, supra note 4, at 1910. 
If creditors wish to retain current management, there is no good reason why they should be prevented from doing so. But it is hard to understand why that requires some concession to stockholders. Why can't management be paid a salary or given claims on the reorganized firm? Such claims are what the old stockholders will get in any case, if they get anything.

It is an open question whether the managerial-retention case is empirically important, but a somewhat similar phenomenon mentioned briefly above is no doubt important. As a corporation approaches insolvency, it will become more and more attractive to the stockholders to have management convert assets into cash and pay the cash out as dividends. There are constraints on what management can do to serve these interests, but such constraints cannot be fully effective. One conversion opportunity which is very difficult to monitor is the abandonment of maintenance. In the case of the Penn Central, for example, it was practically impossible to tell whether the failure to maintain track beds was efficient or represented a conversion of assets into cash flow for the benefit of stockholders. Given that stockholders have such opportunities, creditors may find it desirable to concede positive shares in bankruptcy to them as a way of discouraging exploitation. This presumes that there is some cost to stockholders of stealing from the creditors and that they will be willing to settle for something less than the gross amount they can steal.

Managerial retention and stockholder conversion of assets are very different from either the valuation problem or the problem of excess power for shareholders under chapter XI. The latter two are simply means by which shareholders are able to retain an equity in a reorganized firm. The first two explain in behavioral terms why both creditors and shareholders would be willing to allow some of that to happen.

\section{Potential Revisions of Corporate Bankruptcy Law}

Both H.R. 31 and H.R. 32, the Bankruptcy Act revisions that were introduced in the Ninety-fourth Congress, would alter corporate bankruptcy ground rules. In detail, both would make extensive changes in existing procedures, but in the corporate area the major substantive change would be to bring all corporate bankruptcies under something much closer to chapter XI procedures. In particular, the revisions would significantly soften rigid adherence to absolute priority in settlement of claims under chapter $\mathrm{X}$. This will tend to give shareholders in publicly held corporations more power in bankruptcy than they currently possess. Meanwhile the revisions more or less ignore the problem of valuation of a firm.

To this economist, at any rate, what is disappointing about the deliberations which have surrounded the proposed revisions, including the work of the Commission, is their failure to look at radical alternatives to the present 
structure. The valuation problem is a case in point. As a result of intensive research over the last decade or so, we now know a great deal about how the value of firms is determined in financial markets. ${ }^{61}$ Most of us would have little faith that estimates derived by the SEC staff would be superior to those that markets would generate. Why not use the market to determine the value of the firm? Indeed, why not simply hold auctions for firms which go into bankruptcy, or issue claims on firms in bankruptcy and use their value to fix the value of the firm? Such a scheme combined with an absolute priority rule would reduce much of the arbitrariness inherent in present procedures. Moreover, it would substitute businessmen with the right incentives for the courts in reorganizations. It would be of some solace to a few of us in the economics community to have such possibilities given careful study before a new complex set of ground rules is adopted.

61. Warner made a detailed study of the return on 73 securities representing claims on 20 bankrupt railroads during the period of bankruptcy. Warner, supra note 58 , at 240 . He concludes:

While the market appears to have been characterized by an absence of gross inefficiencies in the 1935-1939 and 1943-1955 periods, ex ante profit opportunities may well have been available to investors who bought the sample bonds in the early 1940's. With the exception of that period, though, the evidence does not allow us to reject the view that the capital market was aware of the possibility of deviations from the absolute priority rule, and reflected that understanding in setting prices on risky debt claims.

Id. at 272. This study suggests that the abnormal returns in the early forties can be explained by changes in the law during that period that were favorable to creditors in railroad reorganizations. 